\title{
STUDY OF THE IRON ATOM CLUSTERING IN MECHANICALLY ALLOYED Al-RICH Fe-Al MIXTURE
}

\author{
V. Bèčytè, K. Mažeika, and R. Juškènas \\ Center for Physical Sciences and Technology, Savanoriu 231, LT-02300 Vilnius, Lithuania \\ E-mail: violeta.becyte@gmail.com
}

Received 23 October 2013; revised 5 February 2014; accepted 29 May 2014

\begin{abstract}
Structural changes in the Fe-Al system modified by high-energy ball milling were studied using Mössbauer spectroscopy and $\mathrm{X}$-ray diffraction. Pure Fe and Al powders were mixed in compositions with $0.5,1.5$, and 5 at.\% Fe and milled for various times using the Fritsch Pulverisette planetary mill. The formation of iron clusters was observed when the percentage of paramagnetic iron was higher than 0.5 at.\%. It was found that the arrangement of Fe atoms in iron clusters is similar to that observed in FeAl ${ }_{n}$ $(n \geq 2)$ intermetallic compounds.
\end{abstract}

Keywords: Mössbauer spectroscopy, ball milling, clusters, nanoparticles

PACS: 78.40.Kc, 61.66.Dk, 81.30.Bx

\section{Introduction}

Structural components made of aluminium and its alloys are important in aerospace industry and areas of transportation and building [1]. Iron-aluminium alloys may also attract considerable interest due to such properties as high oxidation and corrosion resistance as well as low cost [2]. Among various methods to synthesize iron-aluminium alloys, high-energy ball milling presents an opportunity in preparing relatively large amounts of nanocrystalline materials with interesting technological properties affected by a large volume fraction of atoms residing in grain boundaries [3-10]. In investigating the Al-rich $\mathrm{Al}-\mathrm{Fe}$ system, previously it has been reported that conditions of synthesis have a major influence on the structure of alloys [11-14]. The magnetism in the nonmagnetic ordered Fe-Al alloy (B2 structure) was induced by the ball milling because of the iron atom clustering on the grain boundaries [9]. Furthermore, a similar low temperature magnetism of Al-rich Fe-Al alloys was also observed for the $\mathrm{FeAl}_{2}$ intermetallic compound having a more complicated $\mathrm{Fe}-\mathrm{Al}$ atom ordering where iron atoms have a different number of iron atoms in their neighbourhood 115,16 . Theoretical calculations of the ground state of $(\mathrm{FeAl})_{\mathrm{n}}$ $(n \leq 6)$ clusters revealed that iron atoms cluster due to the domination of Fe-Fe atom interactions [17]. According to the study [18] the nanoscale segregation (clustering) of $\mathrm{Fe}$ atoms while doping aluminium with
Fe below 2 at.\% is essential for the mechanical properties of the alloys. In rapidly quenched samples, supersaturated solution $\mathrm{Al}(\mathrm{Fe})$ existed in a composition of up to $4-6$ at.\% of Fe [19, 20]. After comparing a rapidly quenched $\mathrm{Fe}_{2} \mathrm{Al}_{98}$ sample with the ball milled sample of the same composition it was found that while the supersaturated solution $\mathrm{Al}(\mathrm{Fe})$ was mostly preserved in the quenched sample, an amorphous-like structure formed in a ball milled one due to Fe atom clustering [12]. Still, only a few studies investigated ball milled compositions with less than 5 at.\% of Fe [11, 12]. The formation of $\mathrm{Fe}-\mathrm{Al}$ clusters on grain boundaries may have some influence on the magnetic properties of the sample [11] in the primary stage of milling, but in the case of $\mathrm{Fe}_{2} \mathrm{Al}_{98}$ composition, clustering of iron atoms does not lead to magnetic ordering for a longer milling time [12].

Research in a broader range of compositions processed by high-energy ball milling was performed in this study to investigate properties of $\mathrm{Fe}-\mathrm{Al}$ clusters within the limits of supersaturated solutions, i. e. up to 5 at.\% of Fe at different stages of alloying.

\section{Experiment}

Fe powder of $99.5 \%$ purity (Sigma Aldrich) and $\mathrm{Al}$ powder (99\%, Sigma Aldrich) were mixed in compositions of $0.5,1.5$, and 5 at.\% Fe. Milling of these mixtures was performed using a Fritsch Pulverisette 6 planetary mono-mill equipped with a $250 \mathrm{ml}$ hardened steel vial 
and 1200 steel balls of $0.5 \mathrm{~g}$ mass each (ball-to-powder ratio 1:20) under nitrogen atmosphere for various times of $2 \mathrm{~h}, 5 \mathrm{~h}, 7 \mathrm{~h}$, and $10 \mathrm{~h}$. In addition, $1.5 \mathrm{at} \% \mathrm{Fe}$ composition was milled up to $25 \mathrm{~h}$. Ethanol $(0.05 \mathrm{ml} / \mathrm{g}$ of powder) was added as a lubricant agent to avoid aluminium sticking to the milling media. The total mass of initial powder mixture $m_{\text {(total) }}$ was $30 \mathrm{~g}$. Changes in composition of milled samples were characterized using Mössbauer spectrometry and X-ray diffraction. The Mössbauer spectra were measured at room temperature using a conventional spectrometer in transmission geometry with a ${ }^{57} \mathrm{Co}(\mathrm{Rh})$ source and analysed using SITE and DIST of NORMOS program pack. The Mössbauer spectra were characterized by evaluating relative amounts of a magnetically split ferromagnetic $(\alpha-\mathrm{Fe})$ phase with a hyperfine field of $33.1 \mathrm{~T}$ and ferromagnetic (with the hyperfine field less than $33.1 \mathrm{~T}$ ) and paramagnetic intermetallic compounds. The contribution of paramagnetic compounds is fitted by the application of the singlet or doublet.

XRD data have been collected using Bruker AXS diffractometer equipped with the $\mathrm{Cu} K_{\alpha}$ source $(\lambda=1.5418 \AA)$. The crystallite sizes were determined on the basis of a broadening of the peaks in an $\mathrm{X}$-ray diffraction pattern as is described by the Scherrer Equation:

$$
D_{\mathrm{p}}=\frac{0.94 \lambda}{\beta_{1 / 2} \cos \theta},
$$

where $\lambda$ is source wavelength and $\beta_{1 / 2}$ is the peak full width at half maximum (FWHM).

\section{Results and discussions}

The hyperfine parameters of iron-based alloys strongly depend on the configurations of Fe nearest neighbours in the lattice [12, 13,21, 22]. The formation of a nonmagnetic iron can primarily be explained by the dissolved $\mathrm{Fe}$ atoms in $\mathrm{Al}$. Only when the iron atom has less than four Fe atoms as nearest neighbours, a nonmagnetic state is observed [21]. Because of the difference in $\mathrm{Fe}$ and $\mathrm{Al}$ atomic radius and lattice type (Fe has a bcc crystal structure, Al has a fcc crystal structure) the process of mixing is complicated as many different intermetallic compounds can form in.

The Mössbauer spectra (Figs. 1, 2) consist of both magnetic and nonmagnetic subspectral components. A doublet or singlet which corresponds to a paramagnetic subspectral component is seen in all of the milled samples. The relative contribution of the paramagnetic compounds to Mössbauer spectra, $S_{\text {par }}$ increases with increasing milling time (Fig. 3). The variation in isomer shift $\delta$ as well as in quadru-

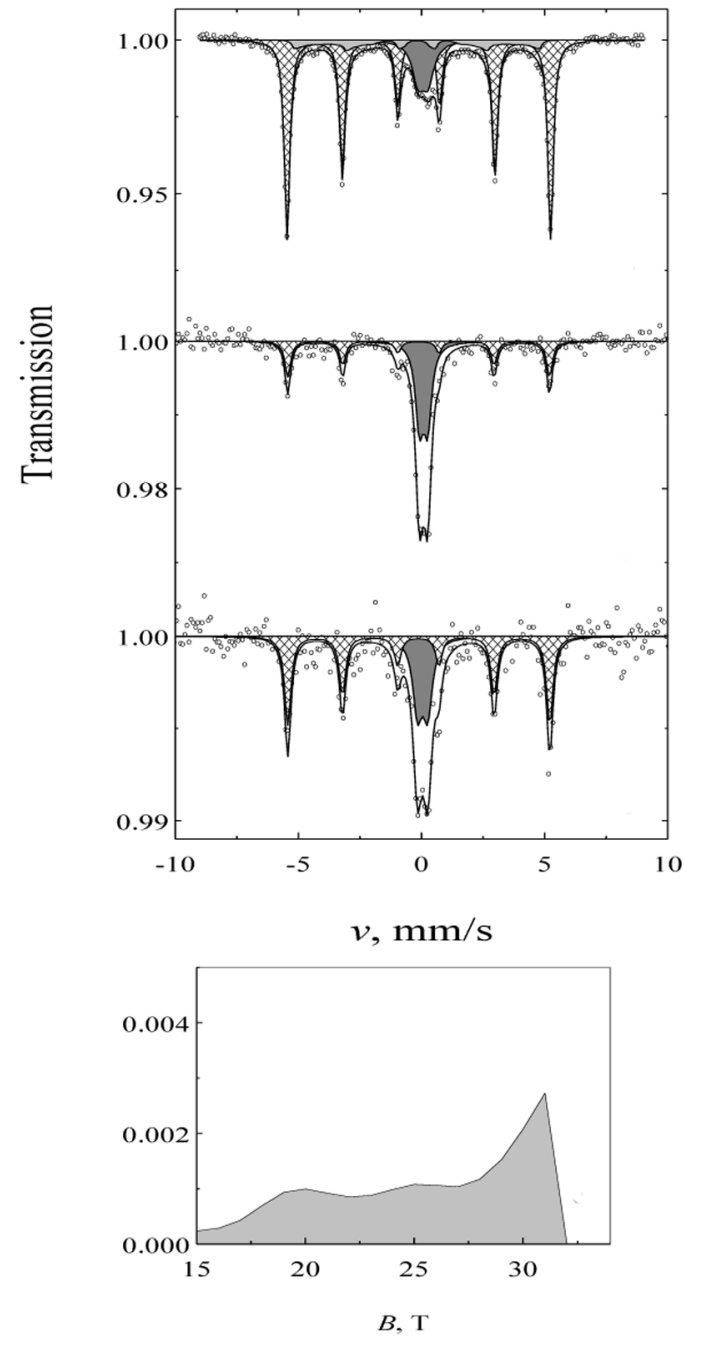

$\mathrm{P}(B)$

(a)

(b)

(c)

Fig. 1. Mössbauer spectra of $\mathrm{Fe}_{x} \mathrm{Al}_{100-x}$ powders milled for $10 \mathrm{~h}$ and measured at room temperature when $x=5(\mathrm{a})$, 1.5 (b), and 0.5 (c). Hyperfine field distribution (d) is shown for spectrum (a).

pole splitting $\Delta$ (Figs. 3, 4) indicates the changes in the neighbourhood of Fe atom. An increase in isomer shift for paramagnetic iron atoms is observed up to 10 hours of milling time (Fig. 3) for $\mathrm{Fe}_{1.5} \mathrm{Al}_{98.5}$ powder composition. The isomer shift increases initially to the characteristic value of $0.38 \mathrm{~mm} / \mathrm{s}$, which corresponds to the isolated $\mathrm{Fe}$ atoms in $\mathrm{Al}$ matrix, and in Mössbauer spectra is fitted to a singlet [12, 13, 22]. However, with increased percentage of paramagnetic iron, the paramagnetic part of the spectrum is fitted to a doublet. Moreover, certain changes in isomer shift and quadrupole splitting occur further with increased milling time and percentage of paramagnetic iron (Fig. $4(\mathrm{a})$ ).

Solubility of $\mathrm{Fe}$ in $\mathrm{Al}$ matrix can be extended up to 5 at.\% by mechanical alloying [11, 12]. The diffusion 


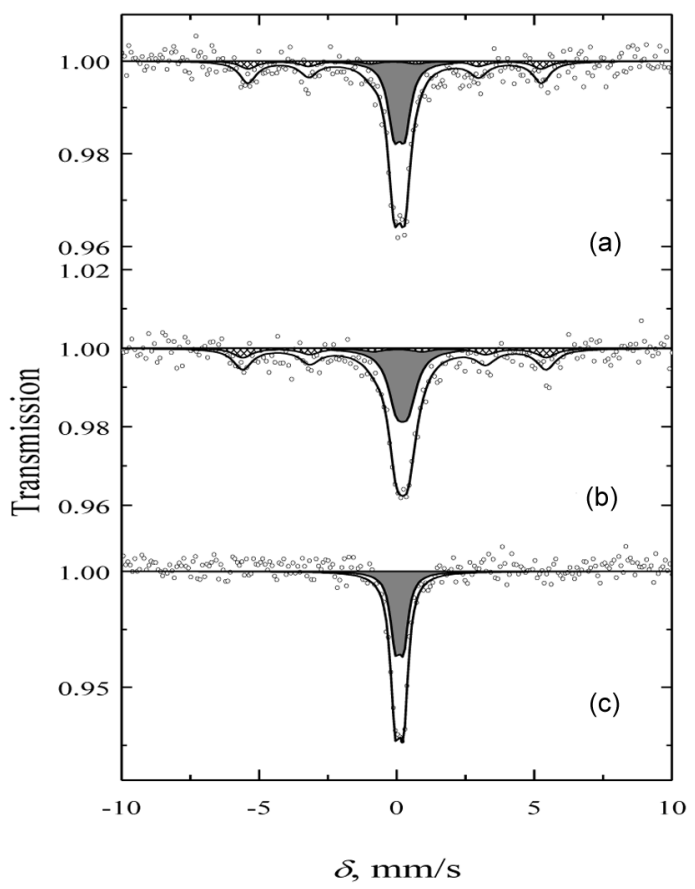

Fig. 2. Mössbauer spectra of $\mathrm{Fe}_{1.5} \mathrm{Al}_{98.5}$ milled for $25 \mathrm{~h}$ milling time measured at room temperature $(\mathrm{a}, \mathrm{c})$, at $14 \mathrm{~K}(\mathrm{~b})$, and annealed at $600{ }^{\circ} \mathrm{C}$ for $2 \mathrm{~h}$ (c).

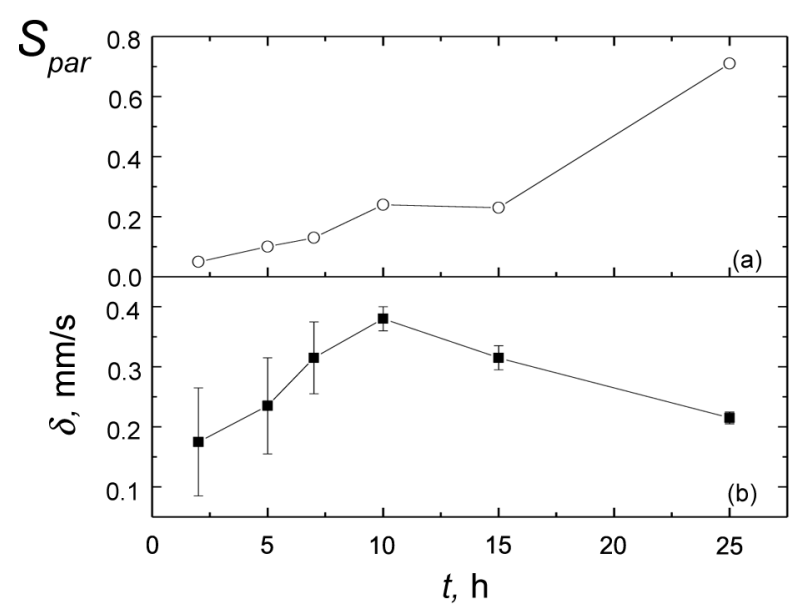

Fig. 3. Dependence of the relative area of paramagnetic $\mathrm{Fe}$ (a) and average isomer shift (b) on milling time for $\mathrm{Fe}_{1.5} \mathrm{Al}_{98.5}$.

of iron atoms in $\mathrm{Al}$ matrix is facilitated by forming a larger number of defects and grain interfaces as the grain size decreases with milling time increasing (Table 1) according to X-ray data (Fig. 5). Due to a low percentage of iron, only information on $\mathrm{Al}$ is available from X-ray data. A larger number of iron atoms in aluminium matrix is causing clustering, and therefore, a doublet is seen instead of a singlet [12].

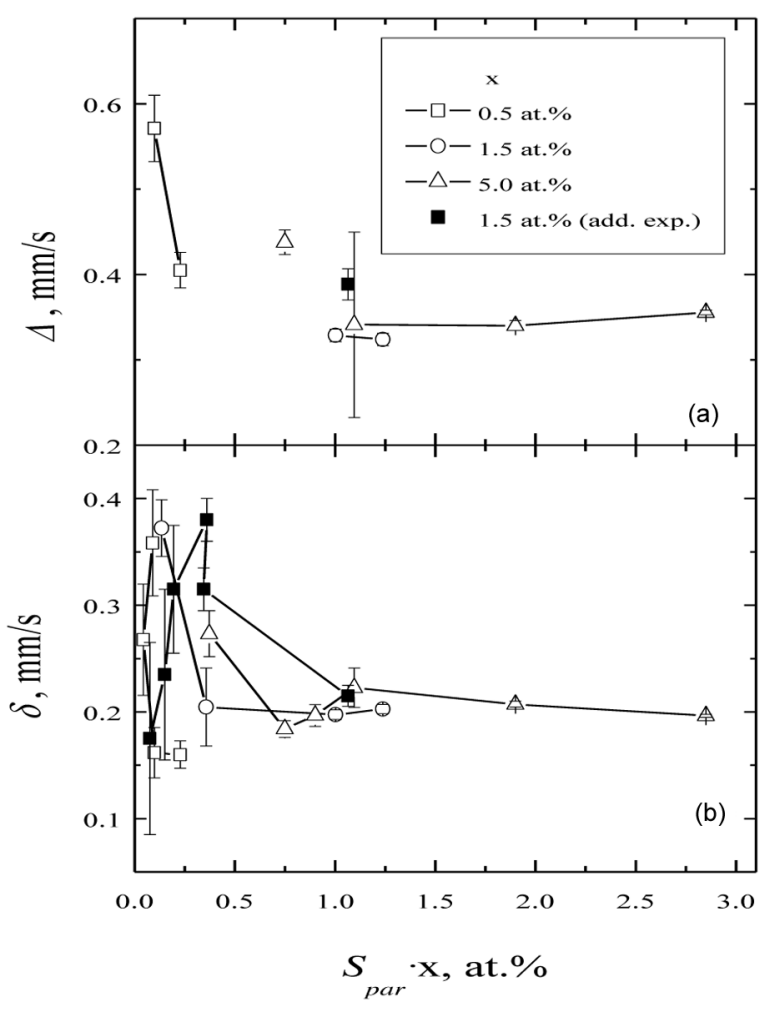

Fig. 4. Dependence of (a) quadrupole splitting and (b) isomer shift of paramagnetic compounds on average concentration of paramagnetic iron in aluminium expressed by $S_{\mathrm{par}} \cdot x$.

Table 1. Crystallite sizes of $\mathrm{Al}$ powder and $\mathrm{Fe}_{x} \mathrm{Al}_{100-x}$ samples milled for $10 \mathrm{~h}$.

\begin{tabular}{cc}
\hline Sample & $D, \mathrm{~nm}$ \\
\hline Pure Al & 81.5 \\
\hline $\mathrm{Fe}_{0.5} \mathrm{Al}_{99.5}$ & 27.1 \\
\hline $\mathrm{Fe}_{1.5} \mathrm{Al}_{98.5}$ & 27.6 \\
\hline $\mathrm{Fe}_{5} \mathrm{Al}_{95}$ & 22.5 \\
\hline
\end{tabular}

Due to the clustering of $\mathrm{Fe}$ atoms, a large number of environments specific to nonmagnetic intermetallic $\mathrm{Fe}-\mathrm{Al}$ compounds can form and be responsible for the formation of the nonmagnetic part of the Mössbauer spectrum [1]. The spectra of paramagnetic intermetallic compounds of $\mathrm{Fe}-\mathrm{Al}$ : triclinic $\mathrm{FeAl}_{2}$ $(\delta=0.108 \mathrm{~mm} / \mathrm{s}, \Delta=0.432 \mathrm{~mm} / \mathrm{s}$ and $\delta=0.278 \mathrm{~mm} / \mathrm{s}$, $\Delta=0.451 \mathrm{~mm} / \mathrm{s}$ [16]) and orthorhombic $\mathrm{Fe}_{2} \mathrm{Al}_{5}$ $(\delta=0.22 \pm 0.01 \mathrm{~mm} / \mathrm{s}, \Delta=0.48 \pm 0.01 \mathrm{~mm} / \mathrm{s}[23])^{5}$ have a larger quadrupole splitting than that existing in Mössbauer spectra of our $\mathrm{Fe}_{x} \mathrm{Al}_{100-x}$ samples when the percentage of paramagnetic iron is larger than $\approx 1$ at.\% (Fig. 4). Accordingly, the parameters which have been found for longer milling times are more similar to those of monoclinic $\mathrm{FeAl}_{3}$ or metastable $\mathrm{FeAl}_{6}$ 


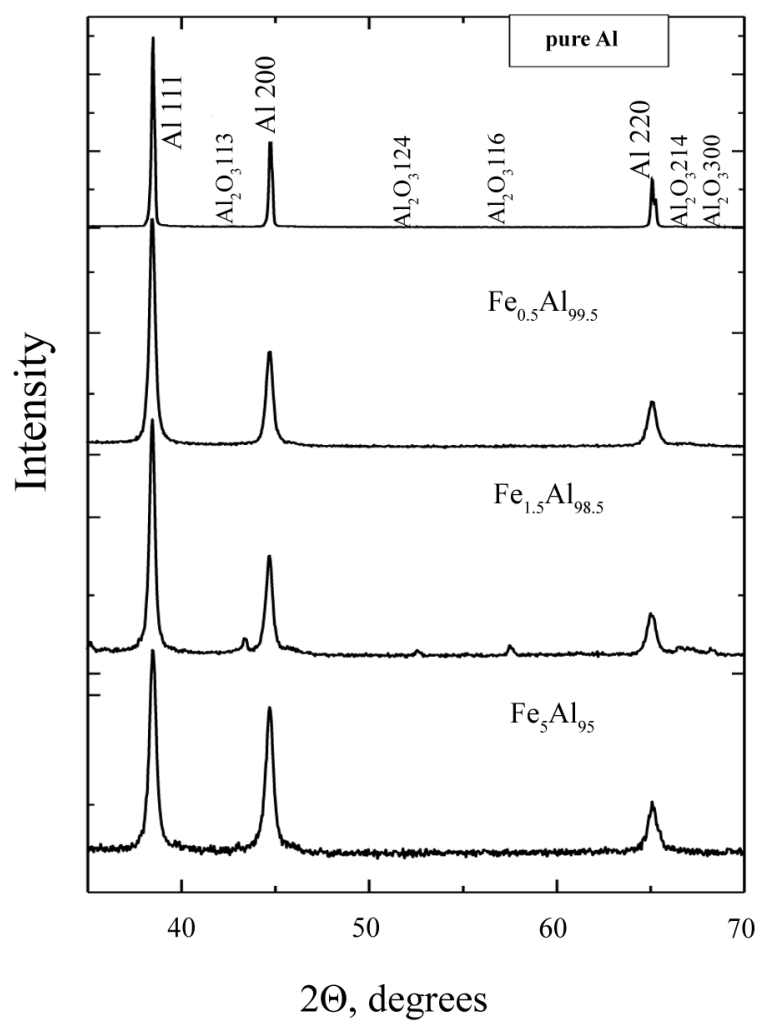

Fig. 5. X-ray diffraction patterns of samples.

[13, 14]. Though the Mössbauer spectrum of intermetallic compound $\mathrm{FeAl}_{3}$ is usually fitted to three singlets of equal intensity with isomer shifts $\delta=0.01,0.19$, and $0.38 \mathrm{~mm} / \mathrm{s}$ [13] the spread of overlapping lines of the spectrum is close to those for $\mathrm{FeAl}_{6}$ with a spectrum consisting of one doublet with $\delta=0.23 \mathrm{~mm} / \mathrm{s}$ and $\Delta=0.32 \mathrm{~mm} / \mathrm{s}$ [13, 14]. Moreover, the variety of metastable compounds with composition $\mathrm{FeAl}_{n}(n>3)$ are possible to form [13].

After annealing at $600{ }^{\circ} \mathrm{C}$, quadrupole splitting of a doublet for the $\mathrm{Fe}_{1.5} \mathrm{Al}_{98.5}$ sample milled for $25 \mathrm{~h}$ decreased from $\Delta=0.38 \mathrm{~mm} / \mathrm{s}$ to $\Delta=0.31 \mathrm{~mm} / \mathrm{s}$ (Fig. 2(c)), showing that the metastable supersaturated Fe solutions in $\mathrm{Al}$ formed.

It is noted that with milling time increasing lower hyperfine field values $(B<33.1 \mathrm{~T})$ are observed for the $\mathrm{Fe}_{5} \mathrm{Al}_{95}$ sample (Fig. 1 (d)). The formation of solid solution of aluminium in iron $\mathrm{Fe}(\mathrm{Al})$ and intermetallic compound $\mathrm{Fe}_{3} \mathrm{Al}$ [24] is observed. These intermetallic alloys may form in all the samples, but they are less evident in the samples with a lower Fe percentage.

The measurements at low temperature (Fig. 2(b)) did not show noticeable changes in the Mössbauer spectra compared to those measured at room temperature, indicating that no superparamagnetic intermetallic or intermetallic compound having the magnetic transition temperature below the room temperature exists.

The previous results for milled $\mathrm{Fe}-\mathrm{Al}$ composition samples with a low percentage of Fe considerably differ from those reported in this paper [11, 12]. It can be explained by the difference in milling conditions and achieved state of a milled sample [11, 12]. The main part of the Mössbauer spectrum of the sample in the nonmagnetic state was fitted to a doublet and attributed to nonmagnetic clusters of Fe atoms [12]. However, when a considerably smaller extent of mixing or alloying of $\mathrm{Fe}$ and $\mathrm{Al}$ elements was achieved, the amount of observed magnetic Fe was still significant. In this case the iron atoms clustering could cause the changes in magnetic properties of the sample. It is shown that the iron atoms residing on the grain boundaries have influence on the magnetic properties of the iron-rich samples, i. e. FeAl and $\mathrm{Fe}_{3} \mathrm{Al}$ intermetallic compounds after milling, as the grain size decreased with milling time [9, 25].

\section{Conclusions}

A study of milled $\mathrm{Fe}_{x} \mathrm{Al}_{100-x}$ nanocomposites with $x=0.5,1.5$, and 5 at. $\%$ of Fe showed differences for paramagnetic fraction of the sample which can be approximately related to the percentage of paramagnetic iron in $\mathrm{Al}$ matrix. When the percentage of paramagnetic iron $\left(S_{\text {par }} \cdot x\right)$ is low (below 0.5 at.\%) the major part of paramagnetic iron atoms is in aluminium matrix forming the solution $\mathrm{Al}(\mathrm{Fe})$. However, for longer milling times, the $\mathrm{Al}(\mathrm{Fe})$ solution would become supersaturated, and therefore, the clusters of iron atoms are formed. According to the values of isomer shift and quadrupole splitting of a doublet used for the paramagnetic part of the Mössbauer spectrum, the atom ordering in iron clusters is similar to those of $\mathrm{FeAl}_{n}$ $(n=2,2.5,3,6)$ intermetallic compounds when the percentage of paramagnetic iron in samples is larger than 0.5 at. $\%$ of Fe. For the percentage of $1-3$ at.\% of paramagnetic $\mathrm{Fe}$, the quadrupole splitting decreases up to $0.32 \mathrm{~mm} / \mathrm{s}$ indicating that $\mathrm{Fe}$ and $\mathrm{Al}$ atoms arrange similarly to $\mathrm{FeAl}_{n}$ compounds with $n \geq 3$.

\section{References}

[1] M. Potesser, T. Schoeber, H. Antrekowitsch, and J. Bruckner, The characterization of the intermetallic Fe-Al layer of steel-aluminum weldings, in: EPD Congress, eds. S.M. Howard et al. (Curran Associates, Inc., 2006 ) pp. 167-176.

[2] R. Prescott and M.J. Graham, The oxidation of ironaluminium alloys, Oxidation of Metals 38, 73-87 (1992). 
[3] C. Suryanarayana, Mechanical alloying and milling, Progr. in Mater. Sci. 46, 1-184 (2001).

[4] F. Cardellini, V. Contini, R. Gupta, G. Mezzone, A. Montone, A. Perin, and G. Principi, Microstructural evolution of Al-Fe powder mixtures during high-energy ball milling, J. Mater. Sci. 33, 2519-2527 (1998).

[5] S. Enzo, F. Frattini, G. Mulas, and G. Principi, Structural transformation of Al-Fe alloys analyzed by neutron diffraction and Mössbauer spectroscopy, J. Mater. Sci. 39, 6333-6339 (2004).

[6] L. D’ Angelo, L. D’ Onofrio, and G. Gonzalez, Nanophase intermetallic FeAl obtained by sintering after mechanical alloying, J. Alloys Comp. 483, 154-158 (2009).

[7] V. Sebastian, N. Lakshmi, and K. Venugopalan, Correlation between microstructure and magnetic properties in mechanically alloyed nanogranular $\mathrm{Fe}_{100-\mathrm{x}} \mathrm{Al}_{\mathrm{x}}$, Mater. Lett. 61, 4635-4638 (2007).

[8] M.A. Meyers, A. Mishra, and D.J. Benson, Mechanical properties of nanocrystalline materials, Progr. in Mater. Sci. 51, 427-556 (2006).

[9] L.F. Kiss, D. Kaptàs, J. Balogh, L. Bujdosó, T. Kemény, and L. Vincze, Rigid magnetic foam- like behavior in ball- milled FeAl, Phys. Rev. B 70, 012408 (2004).

[10]K. Mažeika, J. Reklaitis, G. Lujanienè, D. Baltrūnas, A. Baltušnikas, Modification of nanocrystalline magnetite by milling, Lith. J. Phys. 46(4), 451-457 (2006).

[11] V. Sebastian, N. Lakshmi, and K. Venugopalan, Evolution of magnetic order in mechanically alloyed $\mathrm{Al}-1$ at.\% Fe, J. Magn. Magn. Mater. 309, 153-159 (2007).

[12]R.A. Dunlap, J.R. Dahn, D.A. Eelman, and G.R. MacKay, Microstructure of supersaturated fcc Al-Fe alloys: A comparison of rapidly quenched and mechanically alloyed $\mathrm{Al}_{98} \mathrm{Fe}_{2}$, Hyperfine Interact. 116, 117-126 (1998).

[13]L. Murgas, Z. Homonnay, S. Nagy, and A. Vertes, Investigation of phase transformation in an Al0.58 wt\% Fe alloy by Mössbauer spectroscopy, Hyperfine Interact. 41, 595-598 (1988).

[14] R.A. Dunlap, K. Dini, G. Stroink, G.S. Collins, and S. Jha, An Fe Mössbauer effect study of metastable
$\mathrm{Al}_{86} \mathrm{Fe}_{14}$ prepared by rapid solidification, Hyperfine Interact. 28, 963-966 (1986).

[15] Ji Chi, Yang Li, F.G. Vagizov, V. Goruganti, and J.H. Ross, NMR and Mössbauer study of spin-glass behavior in $\mathrm{FeAl}_{2}$, Phys. Rev. B 71, 024431(2005).

[16]D. Kaptàs, E. Sváb, Z. Samogyvàri, G. André, J. Balogh, L. Bujdosó, T. Kemény, and L. Vincze, Intercommensurate antiferromagnetism in $\mathrm{FeAl}_{2}$ : Magnetic, Mössbauer, and neutron diffraction measurements, Phys. Rev. B 73, 012401 (2006).

[17]B.V. Reddy, S.N. Khanna, and S.C. Deevi, Electronic structure and magnetism in $(\mathrm{FeAl})_{\mathrm{n}} \mathrm{n} \leq 6$ clusters, Chem. Phys. Lett. 333, 465-470 (2001).

[18] T. Mukai, S. Suresh, K. Kita, H. Sasaki, N. Kobayashi, K. Higashi, and A. Inoue, Nanostructured Al-Fe alloys produced by e-beam deposition: static and dynamic tensile properties, Acta Mater. 51, 41974208 (2003).

[19] R.A. Dunlap, D.J. Lloyd, I.A. Christie, G. Stroink, and Z.M. Stadnik, Physical properties of rapidly quenched Al-Fe alloys, J. Phys. F Met. Phys. 18, 1329-1341 (1988).

[20] S. Nasu, U. Gonser, P.H. Shingu, and Y. Murakami, ${ }^{57} \mathrm{Fe}$ Mossbauer spectra in splat quenched A1-0.5, 1, 3 and 5 at.\% Fe alloys, J. Phys. F Met. Phys. 4, L24-L28 (1974).

[21]D.A. Eelman, J.R. Dahn, G.R. MacKay, and R.A. Dunlap, An investigation of mechanically alloyed Fe-Al, J. Alloys Comp. 266, 234-240 (1998).

[22] I. Dezsi, U. Gonser, and G. Langouche, Systematics of the isomer shifts of ${ }^{57} \mathrm{Fe}$ in various hosts, Phys. Rev. Lett. 62(14), 1659-1662 (1989).

[23] E.P. Yelsukov, A.L. Ul'yanov, A.V. Protasov, and D.A. Kolodkin, Solid state reactions upon mechanical alloying of an $\mathrm{Fe}_{32} \mathrm{Al}_{68}$ binary mixture, Phys. Met. Metallogr. 113(6), 602-611 (2012).

[24] J.E. Frackowiak, Mössbauer isomer shift and hyperfine fields of ordered and disordered $\mathrm{Fe}_{3} \mathrm{Al}$ alloys, Hyperfine Interact. 54, 793-798 (1990).

[25] J. Nehra, S. Jani, V.D. Sudheesh, K. Kabra, L. Nambakkat, and K. Venugopalan, Variation of magnetic properties in heat treated and ball milled $\mathrm{Fe}_{3} \mathrm{Al}$ alloy, Hyperfine Interact. 211, 123-133 (2012).

\title{
GELEŽIES ATOMŲ GRUPAVIMOSI MALTAME Fe-Al MIŠINYJE TYRIMAS
}

\author{
V. Běčytè, K. Mažeika, R. Juškėnas \\ Fizinių ir technologijos mokslu centras, Vilnius, Lietuva
}

\section{Santrauka}

Nanokristaliniai geležies ir aliuminio milteliai buvo malami azoto atmosferoje rutuliniu Pulverisette malūnu. Fe atomų būsenos pokyčiai stebèti Mesbauerio (Mössbauer) spektroskopijos ir Rengeno difrakcijos metodais. Pasinaudojus Mesbauerio spektroskopijos metodu gautais pa- rametrais, ịvertintas susidariusių geležies būsenų kitimas didinant malimo trukmę. Paramagnetinès geležies būsenų kitimas gali būti paaiškinamas geležies spiečių susidarymu, kai paramagnetinès geležies atomu kiekis $>0,5$ at.\%. Atominè tvarka geležies spiečiuose turètų būti tokia pati, kaip ir $\mathrm{FeAl}_{n}(n \geq 2)$ intermetaliniuose lydiniuose. 